\title{
WORK CAMPS AND FIGHTING WITH UNEMPLOYMENT IN POST-MUNICH CZECHOSLOVAKIA
}

\author{
[Pracovní tábory a boj s nezaměstnaností v pomnichovském Československu]
}

\author{
Lubomír Nenička ${ }^{1}$ \\ ${ }^{1}$ Slezská univerzita, Obchodně podnikatelská fakulta, Univerzitní nám. 1934/3, 73340 Karviná \\ Email:nenicka@opf.slu.cz
}

\begin{abstract}
The article focuses on changes of social development in post-Munich Czechoslovakia and analyses some new trends of social policy in this period. The particular attention is paid to work camps and its role in social policy of Second Czechoslovak Republic. The work camps should serve not only to decreasing of unemployment, but also to education its members and to agitation for values of new republic. The establishment of work camps in post-Munich era was associated with an suppressing elements of the market economy. The article shows that the service to the nation was presented as the key principle of public life in the Second Republic. The establishment of the work camps was the indication of new tendencies of Czechoslovak social and economic policy.
\end{abstract}

Keywords: refugees, second republic, social politic, unemployment, work camps.

JEL classification: N34, N94

Doručeno redakci: 5.4.2013; Recenzováno: 24.5.2013; 27.5.2013; 4.6.2013; Schváleno k publikování: 16.6.2014

\section{Úvod}

Nezaměstnanost představuje jeden nejpalčivějších sociálních problémů moderní éry. Snahy o jeho řešení ovlivňovaly měnící se podoby sociální politiky v evropských zemích a v USA. První systémy péče o nezaměstané se začaly postupně prosazovat na přelomu 19. a 20. století. Za nesporný přelom nejen $\mathrm{v}$ této oblasti lze považovat velkou hospodářskou krizi, jejímž častým důsledkem byla masová nezaměstnanost. Vlády jednotlivých zemí postižených krizí hledaly ve 30 . letech různé cesty, jak snížit počty lidí bez práce a zabránit tak eskalaci sociálních konfliktů. Mezi často (i když s různým úspěchem) užívané instrumenty patřil institut veřejných prací. Jak bude zmíněno i v následující části, programy veřejných prací byly vyhlašovány $\mathrm{v}$ řadě západoevropských zemí i $\mathrm{v}$ zámoří. Své místo měly také $\mathrm{v}$ sociální politice meziválečného Československa. Následující článek se zabývá jedním ze specifických př́ikladů veřejných prací, které byly zaváděny v letech 1938-1939 v době tzv. druhé republiky. Jde o pracovní útvary, jež byly zřizovány na základě vládního nařízení v reakci na očekávané sociální dopady územních změn po přijetí Mnichovské dohody. Jejich vytvoření a fungování bylo vedenou snahou zabránit narůstající nezaměstnanosti a snížit sociální výdaje. Pracovní útvary byly však také kritizovány jako projev prŕíklonu $\mathrm{k}$ autoritativní formě vlády. Cílem príspěvku je zjistit, jak vytvoření pracovních útvarů souviselo s prosazováním nových tendencí v sociální a hospodářské politice státu. Okolnosti vzniku a fungování pracovních útvarů zde budou přiblíženy na základě poznatků relevantní odborné literatury a studia archivních pramenů různé provenience (zvláště zprávy př́slušných ministertev, okresních úřadů a bezpečnostních složek). Rozsah příspěvku neumožňuje přinést komplexní rozbor činnosti jednotlivých pracovních útvarů a jejich ekonomických výsledků. Výpovědní hodnotu závěrů takové analýzy by navíc limitovalo krátké trvání druhé republiky a následné změny trhu práce po vzniku Protektorátu Čechy a Morava. Článek se tak zaměří především na to, jak bylo vytvoření pracovních útvarů zdůvodňováno na oficiální úrovni a jak bylo členství v nich vnímáno samotnými nezaměstnanými. Analyzovány budou proto zvláště náhledy dobového tisku a také jejich role prri propagaci pracovních útvarů. Jejich efektivnost, př́ípadné problémy 
i mediální obraz budou představeny na konkrétním příkladě vybraného pracovního útvaru.

\section{Podpora nezaměstaných a veřejné práce ve 30. letech 20 . století}

Základním pilířem péče o nezaměstnané v meziválečném Československu byl tzv. gentský systém fakticky zavedený $\mathrm{v}$ roce 1925 , podle něhož byla podpora lidem bez práce rozdělena mezi stát a jednotlivé odborové organizace. Podpora byla proto určena pouze nezaměstnaným členům odborových organizací. Pro československé odbory v době první republiky byla přitom typická značná roztříštěnost, která se do značné míry odvíjela od spojení s politickými stranami. V roce 1937 v Československo působilo 15 odborových ústředen a 688 odborových svazů. Nejvlivnější organizací bylo Odborové sdružení československé (OSČ) spojené se sociální demokracií s více než 450000 členy. Významného postavení dosáhly také národně socialistická Československá obec dělnická (ČOD - 363000 členů) a Republikánské ústř̌edí zaměstnanecké (237 000 členů) (Král, 1958, s. 47). Síla a finanční možnosti jednotlivých odborových centrál také ovlivňovaly vyplacení části podpory. Limity tohoto systému se projevily $\mathrm{v}$ období hospodářské krize, kdy prudce narostl počet nezaměstnaných a jen menší část $\mathrm{z}$ nich mohla využít dřivějšího členství $\mathrm{v}$ odborových organizacích. Také proto vláda na začátku 30. let přijala další doplňující opatření. Nejvýznamnějším z nich byla tzv. státní stravovací akce, jež zahrnovala poskytování potravinových poukázek nezaměstnaným neorganizovaným V odborech (Rákosník, 2008). Dalším nástrojem v boji proti nezaměstnanosti byly veřejně prospěšné práce, které byly $\mathrm{v}$ různé podobě a $\mathrm{s}$ různým úspěchem zaváděny v mnoha zemích postižených hospodářskou krizí. Také v Československu byla zákonem č. 74/1930 Sb. zřízena tzv. státní produktivní péče, která rozvinula už dříve fungující institut nouzových prací. $\mathrm{V}$ jejich rámci měli být nezaměstani nasazováni při realizaci veřejně prospěšných projektů jako byla např. výstavba komunikací. Nevýhodou těchto tzv. nouzových prací byla jejich vyšší nákladnost, která se projevovala zvláště ve srovnáni se státní stravovací akcí. Nicméně v Československu se tato slabina neprojevila $\mathrm{v}$ tak výrazné míře jako v některých jiných zemích jako např. ve Francii (Rákosník a Noha, 2012, s. 142-143).

Kontroverznější formu „nouzových praci““ představovaly pracovní tábory, které byly v Československu zřizovány rovněž od začátku 30. let speciálně pro nezaměstané mladé muže. Ani v tomto případě nešlo o nějaké národní specifikum. Obdobné pracovní tábory byly zakládány $\mathrm{v}$ řadě evropských zemí i v zámoří (USA, Kanada, Nový Zéland). V USA byly po nástupu nového prezidenta Roosevelta $\mathrm{v}$ rámci jeho programu New Deal zřízeny v roce 1933 Civilian Conservation Corps (CCC). Zde měli mladí nezaměstnaní muži pomáhat při práci v národních parcích a různých veřejných prostranstvích. CCC byly zamýšleny i jako svého druhu výchovná instituce, která měla působit preventivně při snižování kriminality. Podle Rooseveltových plánů bylo do CCC v prvním roce jejich existence zařazeno na 250000 mladých nezaměstaných, kteří zde byli izolováni od okolí podrobeni vojenskému režimu. Tábory ukončily svou činnost až v roce 1942. Během devíti let jejich existence jimi prošlo více než 2,5 mil. mladých Američanů (Salmond, 1967). Ve Velké Británii vláda zrrídila první pracovní tábory pro nezaměstnané muže už v polovině 20. let. Deklarovaným cílem těchto institucí, které navazovaly na podobně fungující pracovní kolonie z dřivější doby, bylo zvýšit zaměstnatelnost jejich členů. Jak připomíná Field (2009), výcvik v těchto táborech byl zaměřen zvláště na př́pravu $\mathrm{k}$ předpokládanému vystěhování se do některého $\mathrm{z}$ tehdejších britských domínií (tedy politicky autonomních částí Britského impéria). Pracovní tábory byly zakládány také v nacistickém Německu, kde jejich poněkud odlišný charakter odpovídal praxi totalitního státu. Německé pracovní tábory se lišily především důrazem na povinné členství a výrazněji vojenským stylem řízení. Nelze je však označit za typický projev nacistické sociální politiky; o jejich zrrízení totiž rozhodla vláda Výmarské republiky už v roce 1931 
(Rákosník a Noha, 2012, s. 145). Nacisté stejně jako v př́ípadě některých jiných opatření tento plán převzali a dále rozvinuli v duchu své politiky a ideologie. Také v Československu 30. let zaznívaly pochvalné hlasy vyzdvihující německé pracovní tábory jako možné řešení nezaměstnanosti mladých. Příkladem sympatizujícího prohlášení mohou být slova propagátora pracovních útvarů Josefa Koštálka, který uznával i jistá specifika této instituce v německém pojetí: „Němci všecky svoje organizace zahrocuji vojenským duchem. Nedá se ale popríti, že organizační výsledky jsou velmi dobré, nebot' byly zachráněny před hladem, morální zkázou, zlajdačením a prostituci desetitisíce chlapců a děvčat." (Rákosník a Noha, 2012, s.144-145)

V ČSR byl jeden z prvních pracovních táborů zřízen v roce 1934 v Terezíně, kde pod vojenskou správou pracovalo sto mladých lidí ve věku od 18 do 20 let. (Průcha a kol., 2004, s. 402) V tomto prŕpadě šlo o jednu z tzv. pracovních pospolitostí mládeže, jež zřizovalo ministerstvo sociální péče. Už předtím v Praze působily tzv. pracovní kolony, kam bylo do konce roku 1933 začleněno 11000 nezaměstnaných. Instituce podobného ražení vznikaly $\mathrm{v}$ té době také na Moravě i $\mathrm{v}$ rámci soukromých firem (konkrétně šlo o pracovní tábory Bat’ových závodů) a také na Slovensku. V roce 1935 byly sice pracovní kolony v Praze načas rozpuštěny, ani poté však obdoby pracovních táborů zcela nezmizely a v různých místech a v různých formách se objevovaly i nadále (Deyl, 1985). Pracovní tábory zřizované v první polovině 30 . let však nehrály významnější roli v sociální politice tehdejších vlád. Především na rozdíl od pomnichovského období fungovaly na bázi dobrovolnosti a byly primárně určeny pro nezaměstnanou mládež. I jejich stoupenci navíc poukazovali na to, že jde o dočasná opatření, které si vyžádaly mimořádné důsledky tehdejší hospodářské krize. Podle Rákosníka (2008) výraznějšímu akcentování role pracovních táborů ve státní péči o nezaměstnané bránil také odmítavý postoj sociálnědemokratického ministra sociální péče Jaromíra Nečase.

\section{Vznik a poslání pracovních táborů v pomnichovské ČSR}

Druhá republika byla na dlouhá desetiletí jedním $\mathrm{z}$ posledních období masové nezaměstnanosti v moderních československých dějinách. Jeji zvýšení způsobil zvláště př́liv převážně českých uprchlíků z obsazených pohraničních území, jejichž počet byl odhadován na 335000 (Průcha a kol., 2004, s. 431). Vzrůstající nezaměstnanost ovlivnila také demobilizace vojáků, problémy mnoha podniků, ale i běžné sezónní výkyvy typické pro nadcházející zimní období. V celém pomnichovském Československu bylo ke konci ledna registrováno 180000 neumístěných uchazečů o práci, ovšem skutečné množství nezaměstnaných v té době bylo pravděpodobně výrazně vyšší. Podle odhadů předsedy nově utvořené Státní hospodářské rady Františka X. Hodače, uveřejněných v první polovině února v deníku Venkov, byla skutečná nezaměstnanost o víc než 40000 osob vyšší (Průcha a kol., 2004, s. 445). V dalších měsících oficiální počty lidí bez práce zřetelně poklesly, což byl evidentně také důsledek zahájením sezónních prací. Ve snaze zabránit dalšímu nárůstu nezaměstnanosti vláda pod vedením generála Syrového rozhodla o zř́zení pracovních útvarů (nazývaných také pracovními tábory ${ }^{1}$ ). O jejich vzniku bylo rozhodnuto 11. října 1938 vládním nařízením č. $223 / 1938 \mathrm{Sb}$. Cílem těchto nových institucí bylo snížit počet nezaměstnaných a využít je při veřejně prospěšných pracích. Zřizovatelem pracovních útvarů mělo být do konce roku 1939 ministerstvo národní obrany, jež se na jejich vedení mělo podílet ve spolupráci s ostatními rezorty. Proto také měli v čele útvarů stát vojáci z povolání a jejich př́slušníci měli být podrobeni vojenskému režimu. Členy pracovních táborů se měli stát nezaměstnaní muži ve věku 18-55 let, kteří měli být povoláváni okresními úřady (Gebhart

1 Pracovní útvary, jak zněl jejich název v př́islušném vládním nařízení, byly i na oficiální úrovni nazývány také pracovními tábory. Oba názvy byly tedy fakticky užívány jako synonyma a takto budou uváděny i v tomto článku. 
a Kuklík 2004, s. 176). Zařazení do gentského systému mělo předcházet ohlášení u okresního úřadu, jenž rozhodoval o prrípadném začlenění nezaměstnaných do nově utvářených pracovních táborů. Odmítnutí povolávacího rozkazu mělo být trestáno vyřazením z evidence uchazečů o státní podporu (Rákosník, 2008, s. 26). Jako základní jednotky měly být $\mathrm{v}$ jednotlivých okresech vytvářeny pracovní prapory, členěné dále na roty. Na konci druhé republiky byly ministerstvem sociální a zdravotní správy vydány doplňující směrnice, které dále zpřesňovaly podmínky účasti v pracovních útvarech. Obsahovaly mj. doporučení určené př́slušným okresním úřadům, které měly při náborech upřednostňovat mladší a svobodné muže a rovněž ty, kteří se ve svém běžném zaměstnání vykonávali stejnou nebo podobnou práci jako $\mathrm{v}$ táborech. Také zaměstnavatelé měli př́padná volná místa ve svých podnicích nabízet přednostně vhodným členům pracovních útvarů. Povoláváni neměli být sezónní dělníci, kteří byli tzv. stř́́davě nasazováni do práce. ${ }^{2}$

Pracovní útvary byly také nabízeny jako výhodná pomoc zejména při výstavbě nových komunikací. Př́ślušné okresní úřady nejprve musely splnit podmínky, definované př́slušným vládním nařízením a podrobněji vymezované výnosy zainteresovaných ministerstev a jim podřízených orgánů. Prvním předpokladem $\mathrm{k}$ vytvoření útvarů bylo zajištění práce minimálně pro jednu rotu, již mělo tvořit 150 mužů. Žádosti o jejich zrrízení měly být podány u př́slušných okresních úradů, které je měly opatřit posudky a poslat nejpozději do tří dnů tomu ministerstvu, jehož oboru navrhované práce náležely. V prrípadě schválení projektu měla vojenská správa zajistit organizačně vedení útvarů a provést nábor pracujících. Odborné řízení prací mělo být $v$ rukách zmocněného zástupce samosprávného úřadu, jenž měl být určen podle typu navrhovaných projektů. Náklady za vykonanou práci měly orgány veřejné správy či podnikatelské subjekty hradit podle platných kolektivních smluv hospodářské správě př́slušného pracovního praporu. ${ }^{3}$

V polovině února 1939 působilo v českých zemích celkem 19 pracovních útvarů, v nichž pracovalo 12000 mužů. Tento počet však představoval jen třetinu všech povolaných (Mates, 1989, s. 174). Pracovní tábory tak zůstaly poněkud za očekáváním svých zřizovatelů. Část komunistické historiografie tyto instituce prezentovala jako jeden $\mathrm{z}$ typických projevů fašizačních tendencí pomnichovských vlád v sociální oblasti. Konkrétně Václav Král (1958) tvrdil, že do pracovních táborů byli povoláváni záměrně zejména „pokrokově smýšlejíci“ dělníci, podporovaní odborovými organizacemi. To prý vedlo na jedné straně k oslabovaní odborů, na straně druhé však útvary ovládal „duch revolty“ proti vládnoucí politické reprezentaci. Vláda se prý ve snaze zlomit tento odpor inspirovala nacistickým pŕíkladem a na začátku března 1939 rozhodla o zřízení tzv. kárných pracovních táborů, do nichž měly být umist’ovány „osoby práce se štítici“ (Král, 1958, s. 69). Rozhodnutí o vzniku kárných pracovních táborů lze označit jako projev narůstajících autoritativních tendencí pomnichovského vládnutí, nebylo však primárně zaměřeno proti „pokrokově smýšlejícim“ dělníkům, stoupencům KSČ či dokonce členům levicových odborů. Jak uvádí Sedláková (2004, s. 138), měli zde být umist'ováni sice i „hrubě neukázněni“ příslušnící pracovních útvarů, kárné tábory však byly určeny především osobám považovaným za „povalečské a vyhýbající se práci.

Pojetí pracovních útvarů jako vědomě trestní instituce je tedy nepřesné a zkreslující. Jejich podobu však bezpochyby formovaly změněné vnitropolitické podmínky i nové způsoby

Nové směrnice o odvodech do pracovnich táborư. Lidové listy 8. 3. 1939, č. 56, s. 5.

Viz např. výnos Zemského úřadu $\mathrm{v}$ Brně (ZÚB) z 14. 11. 1938 určený okresním úr̆adům v zemi Moravskoslezské. Státní okresní archiv (SOkA) Frýdek-Místek, f. Okresní úřad ve Frýdku (OÚF) všeobecná registratura, inv. č. 880, kart. 791. 
vládnutí. Podle Rataje (1997) byly pracovní útvary součástí rozsáhlejších změn sociální politiky, jejichž charakter vyjadřovala také slova o „malé sociální revoluci“ uváděná vládním tiskem. Přijetí Mnichovské dohody a její důsledky zdiskreditovaly ideové a politické principy první republiky. Parlamentní demokracie a liberalismus, jejichž důvěryhodností otř́sla výrazně už velká hospodářská krize, byly po Mnichovu odvrženy jako nefunkční a neefektivní. Postupný př́íklon $\mathrm{k}$ autoritativním formám vlády a státní regulaci hospodářství ovlivnil také nové přistupy v sociální oblasti. Mezi ně lze bezesporu řadit právě rozhodnutí o zřízení pracovních útvarů, které padlo už v prvních týdnech po zdrcujícím mnichovském ortelu. Vytváření nových institucí a následný nábor jejich členů provázelo volání po národní jednotě, které později našlo vyjádření v zásadním přebudování politické scény. Snaha zabránit eskalaci sociálních problémů, podporovaná požadavky národní semknutosti a nové „silnější“ demokracie představovaly základní výchozí podmínky pro vznik pracovních útvarů.

Vzhledem $\mathrm{k}$ těmto okolnostem nepřekvapí nekritický až oslavný tón, jimž místní i celostátní tisk vládní Strany národní jednoty (SNJ) referoval o vzniku pracovních útvarů a jejich významu pro boj $\mathrm{s}$ nezaměstnaností. Noviny spojené $\mathrm{s}$ vládním blokem především připomínaly, že vytvoření pracovních útvarů vedlo ke snížení nezaměstnanosti a také přineslo úspory při vyplácení státních podpor. Dalším pozitivem bylo podle tisku zaměstnání všech, kteří se dosud práci vyhýbali. Podnikatelé pak dodávali, že díky založení pracovních táborů vzrostla výkonnost jejich zaměstnanců. ${ }^{4} \mathrm{~V}$ jiných denících padala na adresu útvarů méně pochvalná slova. Napřr. podle komentáŕe listu A-Zet z počátku roku 1939 byla tehdejší podoba pracovních táborů špatným provedením původně dobré myšlenky a proto byla prý žádoucí a nutná jejich reorganizace, $\mathrm{k}$ níž se ostatně schylovalo. ${ }^{5}$ Později na stránkách stejného periodika architekt Zdeněk Husák navrhoval při řízení pracovních útvarů inspirovat se více zahraničními vzory. Konkrétně vyzdvihoval „dobré zkušenosti“ s pracovní službou v Německu, kde jsou velitelé jednotlivých rot skutečnými veliteli s plnou odpovědností a výkonnou mocí. Za efektivnější nástroji v boji proti nezaměstnanosti však pokládal rozvoj soukromého podnikání, které mělo poskytnout potřebná pracovní místa. ${ }^{6}$ Změnit fungování pracovních táborů doporučovaly listy spř́izněné $\mathrm{s}$ někdejší sociální demokracií, transformované do opozičního seskupení, jež vystupovalo nově pod názvem Národní strana práce (NSP). Její vliv limitovala role tzv. loajální opozice, která znemožňovala ve vztahu $\mathrm{k}$ vládě plnit důsledně kontrolní a oponentskou funkci. Také NSP měla totiž pomáhat při budování kýžené národní jednoty a fakticky podporovat vládní kroky. Možnost vykonávat skutečně opoziční politiku byla výrazně omezena postupným př́klonem $\mathrm{k}$ autoritativním formám vlády, jež se projevil mj. posilováním výkonné moci na úkor parlamentu. Ke konci druhé republiky začal být i $\mathrm{v}$ důsledku sílícího německého tlaku zpochybňován existující systém dvou stran. Stále častěji se objevovaly otevřené výzvy k zákazu jediné legální opozice a ustavení skutečně jednotného celonárodního hnutí. Útoky proti NSP ovlivnily také převážně defenzivní ráz veřejných vystoupení jejich představitelů. Jak ukázal Jan Kuklík (1993), bývalí sociální demokraté při různých př́ležitostech však dokázali připomínat hodnoty první republiky i význam demokratických principů. V jejich projevech a v komentáŕích stranického tisku zněly proto i kritičtější hlasy na adresu některých vládních opatření, jak tomu bylo rovněž v př́ípadě pracovních útvarů.

Jejich dosavadní působení i další perspektivy analyzoval na začátku roku 1939 jeden z hlavních opozičních deníků Národní práce. Zmíněné noviny nejprve připomněly, že

\footnotetext{
Dobré výsledky pracovních táborů. Polední Lidové listy 2. 2. 1939, č. 21, s. 3.

V nové republice nesmi býti nikomu ubliženo! A-Zet, 7. 1. 1939, č. 5, s. 3.

Nová velká anketa A-Zetu: ,Je třeba udělat z národa úředníků národ podnikatelü“. A-Zet 23.2. 1939, č. 38, s. 3.
} 
poněkud provizorní fungování pracovních útvarů ovlivnily z velké části mimořádné okolnosti jejich vzniku. Poté list uváděl trri stěžejní nedostatky nových institucí - odvod nezaměstaných bez ohledu na věk, profesi a jejich různou fyzickou úroveň, dále chybějící naději na získání regulérní práce a nakonec nedostatečně motivující způsob hodnocení. List uznával i některé výhody pracovních táborů, mezi něž řadil podíl na snížení nezaměstnanosti a návaznost poskytování podpory na vykonávání veřejně prospěšných prací. Význam těchto pozitiv však snižovaly další slabiny. Také Národní práce varovala před důsledky hrubé práce v táborech pro zručnost kvalifikovaných dělníků a řemeslníků. Členství v pracovních táborech také degradoval fakt, že zde byly vedle běžných nezaměstaných zařazovány i osoby vyhýbající se práci. Povolání do útvarů mohlo $\mathrm{v}$ té souvislosti působit jako trest, snižující lidskou i společenskou důstojnost odvedenců. ${ }^{7}$

\section{Fungování táborů v praxi - příklad pracovního praporu č. 402 v Místku}

Nejednoznačně vyznívajícím komentářům některých periodik odpovídaly také rozporuplné zkušenosti z fungování samotných pracovních táborů. Problémy se objevily už při náborech jejich př́slušníků. $\mathrm{V}$ některých případech městech nespokojenost přerostla $\mathrm{v}$ incidenty, při nichž musela zasahovat policie. Situace se vyhrotila zvláště v Táboře, kde při odvodu do pracovního praporu č. 105 povolaní dělníci i jejich ženy otevřeně protestovali proti svému zařazení do místního útvaru. Proti demonstrujícím zakročila policie a devět $\mathrm{z}$ nich zatkla. Četníci podle zprávy místního okresního úřadu museli zasáhnout i proti ženám a dětem povolanců shromážděným kolem budovy, v nichž se odvody konaly. Někteří odvedenci předtím na výzvy svých žen začali vyskakovat z oken a pokoušeli se uprchnout. Protesty byly evidentně inspirovány KSČ, jejichž členové a stoupenci tvořili zřejmě také podstatnou část povolanců. $^{8}$ Komunistický tisk už předtím opakovaně kritizoval pracovní útvary a poukazoval na jejich nedostatky. Členství v nich prý dělníků znemožňovalo pracovat za řádnou mzdu, za standardních podmínek zaručených kolektivní smlouvou a pod ochranou odborových organizací. Terčem kritiky se stávalo také př́ípadné zaměstnávání kvalifikovaných dělníků, jež by účastí v pracovních táborech mohli ztratit svou odbornost. ${ }^{9}$

Na tomto místě je třeba připomenout, že KSČ byla už v počátcích druhé republiky fakticky vyloučena z politického života. Ke konci ř́jna 1938 byla její činnost zakázána a o několik měsíců později byla strana rozpuštěna. Úrady rovněž zakázaly stranický tisk, zrušily komunistické spolky a poslanci a zastupitelé za KSČ ztratili své mandáty. Tyto změny pochopitelně zásadně limitovaly možnost jejich veřejného působení. Bezprostředně po zákazu činnosti se vedení KSČ rozhodlo postupovat dvojí cestou: komunisté měli jednak infiltrovat stávající politické strany či organizace a jednak měli zahájit př́mou ilegální činnost. ${ }^{10}$ V kritice pracovních táborů se střetávaly obě tyto linie. Jak ukazují př́ípady z Tábora nebo Třebíče, právě komunisté stáli v pozadí zmíněných demonstrací. KSČ se zároveň pokoušela udržet dosavadní politiku jednotné protifašistické fronty, která však už v předmnichovském období narážela na nedůvěru ostatních politických stran. Odpor proti pracovním útvarům nevycházel jen z kruhů blízkých KSČ, kritický postoj zaujali také zástupci odborů. Svědčí o tom zprávy brněnských úradů, které rovněž zaznamenaly rostoucí nespokojenost. I v tomto prŕípadě zazněla obava o dělníky-specialisty, které mohla „hrubá práce v pracovních táborech"

\footnotetext{
7 Pracovní tábory měly by být mostem k slušné existenci. Národní práce 12. 2. 1939, s. 3.

8 Většina $\mathrm{z}$ nich byla později potrestána pokutou vesměs ve výši $50 \mathrm{Kč}$, tři $\mathrm{z}$ nich byli odsouzeni $\mathrm{k}$ na týden „tuhému vězení". Zpráva okresního úřradu v Táboře ze 17.11. 1938. Národní archiv v Praze (NA), f. Prezidium ministerstva vnitra (PMV) - 225, č. kart. 1181, sign. X/P/29/6.

9 Proč chtěji pracovni tábory? Ostravský dělnický deník (ODD) 12. 10. 1938, č. 240, s. 2. Pracovni tábory pro nezaměstnané. ODD 13. 10. 1938, č. 241, s. 1.

10 Výnos PMV určený zemským úřadům v Praze a v Brně. NA, f. PMV - 225, č. kart. 1055, sign. X/K/26.
} 
připravit o jejich zručnost. V reakci na nespokojenost vypracovaly místní ústředny odborových organizací memorandum, kritizující způsob výběru nezaměstnaných a navrhující konkrétní změny podmínek přijímání do pracovních útvarů. Především zde měli být povoláváni muži nezaměstnaní více než šest týdnů, kteří nedostávali žádnou podporu a u nichž mělo být prokazatelně zjištěno, že ve svém oboru práci v brzké době nezískají. Z náboru měli být zcela vyloučeni penzisté, všichni starší i nemocní, ale také dělníci zaměstnávání stř́davě. Členům pracovních útvarů měla být zachována jejich sociální práva, zahrnující všechny druhy pojištění i možnost dovolené. Stejně tak členství v pracovních táborech nemělo vést ke snížení životní úrovně ani $\mathrm{k}$ omezení šancí získat regulérní zaměstnání. Odbory si také $v$ rámci nových institucí hodlaly zachovat svůj vliv a v memorandu žádaly, aby i zde nezaměstnaní mohli být v kontaktu se zástupci svých politických stran a odborových organizací. Samotné členství v pracovních útvarech mělo být celkově volnější - jejich př́śslušníci mohli po dvou měsících práce rozhodnout odejít. ${ }^{11}$ Autory citovaných návrhů byli zástupci odborových organizací spojených se sociální demokracií, národními socialisty a stranou lidovou. Představitelé odborových centrál svázaných s pravicovými složkami SNJ mezi signatáři memoranda chyběli. Předáci Republikánského ústředí zaměstnanců (agrární odbory) a Národního sdružení odborových organizací (Národní sjednocení) v listopadu 1938 opustili už dřive zahájené jednání o společném postupu a pokusili se neúspěšně sjednocení převzít pod svým vedením (Pokorný, 1999, s. 16). Rozpory mezi jednotlivými odborovými organizacemi se projevovaly i ve vztahu k pracovním útvarům a oslabovaly vliv odborového hnutí jako celku.

Konkrétní fungování nové instituce i ohlas její činnosti lze demonstrovat na př́íkladě pracovního praporu č. 402 v Místku. Útvar sídlil a působil kromě samotného Místku také v blízkém Frýdlantě nad Ostravicí. Podle zprávy místeckého okresního úřadu pracovalo v první lokalitě k počátku prosince 99 mužů, v druhém př́ípadě jich bylo 133 . $^{12}$ Podrobnější informace o provozu útvaru poskytuje jiná zpráva okresního úradu v Místku, jež byla jako odpověd' na žádost velitelství 8. divize v Hranicích o zaslání přesného rozvrhu prací praporu, poslána několik dní před jeho zformováním. Hlášení místeckého úřadu z poloviny prosince shrnuje fakta o už zahájené i chystané činnosti praporu. V době napsání zprávy byly zahájeny celkem dva projekty, $\mathrm{v}$ obou prípadech se přitom jednalo o dostavbu dosavadních komunikací. Prvním z nich byla stavba úseku okresní silnice z Moravské Ostravy přes Místek do Turzovky v délce 2,1 km. Náklady stavby ve výši asi 1,7 mil. Kč nesla ministerstva veřejných prací a sociální péče. Druhým projektem byla znovu práce na stejné okresní silnici tentokrát v úseku Kunčičky-Hodoňovice-Frýdlant dlouhém více než $10 \mathrm{~km}$. Náklady v tomto prípadě dosáhly cifry 6,8 mil Kč, hradila je přitom stejná ministerstva jako při prvním projektu. Práce na silnici v obou částech byly zahájeny právě 21. listopadu př́slušníky místeckého pracovního útvaru, jichž v prvním úseku pracovalo 130 na druhém pak 110 . Pravidla pro výběr silničních prací, při nichž by mohly být využity právě pracovní tábory, definovaly pokyny ministerstva veřejných prací (MVP) z počátku listopadu 1938. Tyto směrnice přímo určovaly, že pracovní útvary nemají být nasazovány při stavbě mostů a jiných umělých objektů či budování „,novodobých“ vozovek a dlažeb, jež se zpravidla neobešlo bez účasti patřičně kvalifikovaných dělníků. Návrhy na tyto silniční práce měly být prostřednictvím zemských úradů předkládány MVP, které také rozhodovalo o jejich zařazení do programu staveb prováděných pracovními útvary. ${ }^{13} \mathrm{~V}$ př́ípadě místeckého praporu nároky

\footnotetext{
11 Zpráva policejního ředitelství v Brně Zemskému úřadu v Brně z 5. 12. 1938. NA, f. PMV - 225, č. kart. 1181, sign. X/P/29/6.

12 Situační zpráva Okresního úřadu v Místku (OÚM) pro ZÚB z 2. 12. 1938. SOkA Frýdek-Místek, f. OÚM prez. spisy, inv. č. 522, kart. 73 .

13 Pokyny ministerstva veřejných prací (MVP) tlumočené výnosem ZÚB z 7. 11. 1938. SOkA Frýdek-Místek, f.
} 
úruadů splňovaly jen práce na zmíněné okresní silnici z Moravské Ostravy do Turzovky, na jejichž dostavbu činnost zmíněného útvaru zůstala omezena i v dalším období.

Př́śsušníci tábora měli pracovat 48 hodin týdně jako běžní zaměstnanci. Pracovní doba byla určena dopoledne od 7:30 do 12:00, odpoledne pak od 13:30 do 17 hodin. Od půl šesté do půl sedmé podvečer museli př́slušníci útvaru absolvovat ještě kurz branné výchovy, po jejímž skončení následovala večeře $\mathrm{a} v$ devět hodin měla běžný den $\mathrm{v}$ táboře uzavřít večerka. O sobotách pracovní doba končila o půl druhé odpoledne, zbytek dne měl být věnován čištění oděvů, praní a koupaní. V neděli a během svátků se nepracovalo, př́slušníci útvaru měli svůj volný čas trávit účastí v různých vzdělávacích kurzech (živnostenských, zemědělských, jazykových aj.), nebo návštěvami bohoslužeb či sportováním apod. Pracujícím byla zajištěna strava, ubytování i veškerá výstroj. Kromě toho měli dostávat denní přídavek ve výši 1,50 Kč (velitelé družstev $2 \mathrm{Kč}$, velitelé čet $2,50 \mathrm{Kč}$ ) a př́íplatek za každou odpracovanou hodinu ve výši 40 h. $^{14}$

Samotné zahájení činnosti táboru okomentoval zevrubným článkem Moravskoslezský deník (MSD), místní list pravicového Národního sjednocení. Deník v patřičně propagandistickém duchu přibližoval pestrou sociální strukturu těchto „táboritư“، jak se prý sami nazývali. Mezi nimi tak bylo možno nalézt osmnáctiletého studenta, i „49letého šedivého, ale statného muže“, dále třeba holiče, bývalého majitele zámečnické dílny vyhoštěného Poláky z Karviné, či mladého učitele odvedeného předtím na vojnu, jenž do tábora vstoupil dobrovolně. I on stejně jako všichni ostatní však podle MSD společně pracovali „na novém, lepším Československu“. O významu jejich práce deník nepochyboval: „Zanechají po sobě veliké a dobré dílo. Bude to jejich chlouba, práce prvních „,táboritü“ pod Beskydami. Ale také úsek aktivity naši národní pospolitosti."15 Obsáhlou reportáž o poměrech v útvaru otiskl v Místku vycházející týdeník Bezručův lid. Vztah listu k nové instituci charakterizuje úvodní vzpomínka, vyjadřující obdiv k výkonům čet německé pracovní služby, jichž byl autor článku svědkem v minulém roce v Norimberku. Přání zřídit podobné instituce v předmnichovském Československu bylo vzhledem k povaze „našeho bývalého režimu“ čirou utopií. O provozu místeckého praporu poskytl základní informace listu zástupce velitele škpt. Josef Libosvár, který čtenáře Bezručova lidu informoval, že příslušníky útvaru netvoří „povaleč $i$ či „,hospodští flinkové،, nýbrž absolventi středních škol, učitelé, úředníci, policisté i dělníci. A ti všichni byli s prací v táboře spokojeni - především proto, že ,jejich ruce nemusí zahálet a zbi̊hdarma prijímat podpory“. Naopak byli údajně ještě hrdí na to, že „pomáhají budovat nový, a doufejme lepší, od omyli̊ minulých let osvobozený stát“. Největší část pracujících se podle listu rekrutovala z řad uprchlíkủ, jež spolu s ostatními údajně už dávno navykli vojenskému režimu $\mathrm{v}$ táboře. V závěru svého oslavného komentáře list pracovní tábory označil za symbol změněných poměrů, jež učinily konec i „tzv. kultu 'zasněných rukou'““. Jedině intenzivní práce měla pomoci vybudovat skutečně nový stát. Prvními kameny v jeho základech měly být údajně právě pracovní tábory. ${ }^{16}$

Místní obyvatelstvo však „budovatelské“ nadšení nad vznikem nové instituce př́liš nesdílelo. Podle situační zprávy okresního četnického velitelství v Místku byla ve městě a okolí patrná jistá averze k nově utvořenému pracovnímu táboru. Její příčinou byla především neinformovanost občanů o jeho skutečném poslání a podobě. Toho pak využívali různí

OÚF - všeobecná registratura, inv. č. 880, kart. 791.

14 Zř́zení pracovního tábora vostravském kraji. DČ 20. 11. 1938, č. 274, s. 3. Viz také Pracovní tábor $v$ Mistku. MSD 20. 11. 1938, č. 320, s. 2.

15 V pracovním táboru v Místku. MSD 22. 11. 1938, č. 322, s. 3.

16 První kámen v základech. Bezručův lid 7. 1. 1939, č. 5, s. 1. 
agitátoři - pravděpodobně komunisté - k vykreslování těchto útvarů jako jakési obdoby koncentračních táborů. Tuto agitaci velmi usnadňoval obtížný přístup k rozhlasovému vysílání. Řada jeho předplatitelů vlastnila jen slabší přijímače a nedostávala se tak k poslechu oficiálních tiskových zpráv, které by i nepřesné informace o pracovních táborech uváděly na pravou míru. ${ }^{17}$ Přestože na Místecku žádné výraznější incidenty či projevy nespokojenosti zaznamenány nebyly, jistá nedůvěra k pracovnímu táboru podle všeho panovala i zde. Zprávy některých frýdeckých úřadů naopak ukazují, že místní nezaměstnaní projevovali o vstup do pracovního tábora značný zájem. Obyvatelé frýdeckého okresu se podle telefonického hlášení velitele místeckého praporu pplk. Strejce do něj hlásili ještě před jeho oficiálním povolením. ${ }^{18} \mathrm{Je}$ otázka, nakolik se $\mathrm{v}$ těchto informacích skrýval spíše zájem zástupců vojenské správy zdůraznit význam útvaru, jehož vedením byli pověřeni.

Skutečné postoje uchazečů o práci ve vztahu k pracovním táborům i pocity jejich př́islušníků v regionu však zůstávají nejasné. O pocitech samotných př́islušníků místeckého praporu může vypovídat stížnost některých z nich na chování městské policie v Místku z počátku prosince 1938. Stěžovali si konkrétně pracovníci z řad těšínských uprchlíků, podle nichž se městští policisté chovali urážlivé vůči členům jejich rodin ubytovaných provizorně v místním Lidovém domě a chlapecké škole. Policisté prý mj. pronesli: „Kdybyste byli pořádní lidé, nepotrebovali byste jíti do pracovního tábora." Velitel praporu pplk. Strejc ve své stížnosti na podobné výroky připomínal, že za ztrátou práce v př́padě zmíněných příslušníků jeho útvaru stály politické události a nikdo $\mathrm{z}$ nich na tom nenese vinu. Městský úřad v Místku všechny stížnosti odmítl a naopak poukázal na údajně značnou nekázeň a nepořádnost uprchlíků ubytovaných v místní chlapecké škole. ${ }^{19}$ At’ byly tyto stížnosti oprávněné či ne, vypovídají o tom, jak členství v pracovních táborech mohla vnímat přinejmenším část jejich př́islušníků a jejich nejbližších. Pro české uprchlíky z obsazených území byly sice pracovní tábory př́ležitostí k získání práce, také oni je však viděli spíš jen jako velmi provizorní řešení svých problémů. V místeckém pracovním útvaru našlo podle zprávy místního okresního úřadu z poloviny února práci 78 uprchlíků, kteří měli přechodné bydliště ve zdejším okrese. ${ }^{20}$ Bohužel nejsou k dispozici bližší údaje o jejich sociální struktuře ani o jejich názorech na práci a život v táboře.

I za pracovním táborem v Místku nakonec zůstaly spíše rozpaky a nejednoznačné výsledky. $\mathrm{Na}$ začátku března 1939 bylo do něj podle informací tisku povoláno dalších 150 osob tentokrát z frýdeckého okresu. Z tohoto počtu však 63 mužů neprošlo lékařskou prohlídkou, dalších 40 si mezitím našlo jinou práci a 30 povolanců vůbec nedorazilo. ${ }^{21}$ Tato bilance poněkud zpochybňuje dřivější zprávy o údajném zájmu frýdeckých nezaměstnaných o přijetí. Činnost pracovního útvaru v Místku pokračovala přesto i po vyhlášení protektorátu, ačkoli se několik dní po vpádu německých vojsk v určitých kruzích uvažovalo o jeho zrušení. Příslušné německé vojenské orgány sídlící v Moravské Ostravě však tento záměr odmítly a nařídily $\mathrm{v}$ žádném př́ípadě tábor nerozpouštět. ${ }^{22}$ Místecký prapor tak $\mathrm{i}$ nadále plnil svou

17 Zpráva Okresního četnického velitelství v Místku pro OÚM z 2. 11. 1938. SOkA Frýdek-Místek, f. OÚM prez. spisy, inv. č. 522, kart. 73.

18 Zpráva pplk. Strejce pro OÚ ve Frýdku z 15. 11. 1938. SOkA Frýdek-Místek, f. OÚF - všeobecná registratura, kart. 791, inv. č. 880 .

19 Stížnost pracovního praporu č. 402 z 6. 12. 1938 adresovaná OÚM, protokoly s devíti př́slušníky útvaru z 5. 12. 1938, pokyn OÚM starostovi Místku z 6. 12. 1938 a odpověd’ Městského úřadu v Místku z 27. 1. 1939. SOkA Frýdek-Místek, f. OÚM - prez. spisy, inv. č. 522, kart. 58.

20 Zpráva OÚ v Místku pro ministerstvo sociální péče z 17. 2. 1939. SOkA Frýdek-Místek, f. OÚM všeobecná registratura, inv. č. 895, kart. 1120. Zaměstnávání uprchlíků se věnuje podrobněji další kapitola.

21 Trh práce na Frýdecku. České Slovo 7. 3. 1939, č. 66, s. 2.

22 Hlášení velitele praporu č. 402 z 23. 3. 1939, rozkaz velitelství německého dělostřelectva z Moravské 
funkci, např. v červnu 1939 zde bylo z celkového počtu 195 mužů bez práce zařazeno 159 nezaměstnaných. Ve větší míře však už byli nezaměstnaní najímáni na práci do Německa. V době od 26. dubna do 2. června 1939 se do říše takto v daném obvodu dostalo 440 osob, $\mathrm{z}$ toho 235 nezaměstnaných pocházelo př́mo $\mathrm{z}$ místeckého okresu. ${ }^{23}$ Vzhledem $\mathrm{k}$ této postupné deformaci trhu práce po ustavení Protektorátu Čechy je obtížné hodnotit význam účasti v pracovních útvarech pro další uplatnění jejich členů.

\section{Závěr}

Jak ukazuje př́iklad pracovního praporu č. 402 v Místku, jeho vytvoření evidentně k nějakému výraznějšímu snížení nezaměstnanosti v regionu nepřispělo. Sehrála při tom roli řada faktorů - především nedostatek vhodných prací, při při nichž by se mohly uplatnit nekvalifikované pracovní síly či zimní počasí nevhodné pro zahajování silničních staveb. Při umistování některých skupin nezaměstnaných (konkrétně horníků vypovězených z Těšínska) bylo navíc využíváno možností, jež nabízel průmyslový charakter regionu. V nejednoznačném postoji veřejnosti vůči místeckému táboru se do jisté míry odrážely představy o pracovních táborech jako kárných institucích, jež byly i tady podněcovány zejména komunistickou agitací. Jistou informaci o pověsti místeckého tábora dávají údaje o náboru jeho př́islušníků.. $Z$ více než pěti set povolanců část vůbec nedorazila, nemálo $\mathrm{z}$ př́chozích pak neprošlo lékařskými prohlídkami. Samotný nábor sice neprovázely incidenty jako tomu bylo jinde, část povolanců však k nové instituci cítila zřejmou nedůvěru. Pravděpodobně zvláště uprchlíci těžce pocit’ovali jakékoli narážky, vyjadřující opovržení nad členstvím v útvaru - jak o tom svědčí stížnosti některých z nich na chování místeckých úřadů. Podobné vyjadřování mohlo jen prohlubovat jejich dojem z toho, že je na ně pohlíženo jako na občany druhé kategorie.

Náhlý konec první republiky a jeho tíživé důsledky zpochybnily účinnost standartních řešení. Mimořádné dopady ztráty pohraničního území po přijetí Mnichovské dohody si podle mnohých vyžádaly mimořádné kroky. Vydání vládního nařízení o pracovních útvarech lze jistě řadit mezi ně. Uváděné zdůrazňování budovatelské funkce i výchovného poslání pracovních táborů odhaluje významný rys jejich povahy. Charakter pracovních útvarů totiž lze pochopit nejlépe v kontextu tehdejších společenských změn. Jejich určujícím znakem byl nástup kolektivistického pojetí sociální politiky, jež vyžadovalo podřízení jednotlivce zájmům celku. Nejen $\mathrm{v}$ posledních letech řada historiků $\mathrm{v}$ této souvislosti upozorňuje na nápadné shody mezi hospodářskou a sociální politikou druhé republiky, protektorátu a poválečného Československa. Navzdory řadě odlišností tyto režimy ovládal duch kolektivistických ideologií, zavrhující liberalismus a omezující postavení jednotlivce. Vilém Prečan (1994, s. 32-33) připomínal zdánlivě paradoxní paralely mezi uvedenými režimy, odlišujícími se navenek ideovými principy, sociálním obsahem i zahraničněpolitickou orientací, ale shodujícími se v kritičnosti vůči údajně nízké efektivitě parlamentní demokracie a její liberální sociální a hospodářské politice. Také Miloš Havelka (2009) ve svém př́íspěvku, který se stal podnětem $\mathrm{k}$ hledání možných stop totalitarismu $\mathrm{v}$ českých dějinách, poukázal na vnitřní jednotu ve vývoji české společnosti v letech 1938 až 1956. I podle něj druhou republiku a poválečné období spojovalo zdůrazňování nezbytnosti a mobilizujícího účinku politické a národní jednoty. Vyzdvihování zájmů národně vymezovaného celku se skutečně stalo živým odkazem druhé republiky, jenž se dále rozvinul v následných obdobích. Také účast $\mathrm{v}$ pracovních táborech byla na oficiální úrovni chápána jako národní úkol. Jejich členové byli vládním tiskem oslavováni jako obětaví budovatelé nového řádu. Jan Dobeš (2009) v této souvislosti poukázal na to, že v pomnichovském období byla práce pojímána

Ostravy z téhož dne. SOkA Frýdek-Místek, f. OÚM - prez. spisy, inv. č. 522, kart. 58.

23 Zpráva okresní veřejné zprostředkovatelny práce v Místku pro OÚM. SOkA Frýdek-Místek, f. OÚM - prez. spisy, inv. č. 522, kart. 73 . 
nikoli primárně jako zdroj obživy, ale nově především jako morální povinnost a prostředek k posílení národní existence. Tuto intepretaci potvrzují zveřejněné vládní plány, podle nichž měla být účast $\mathrm{v}$ pracovních táborech výhledově povinná pro všechny muže a nikoli pouze pro nezaměstnané ucházející se o státní podporu. Předseda vlády Beran přitom argumentoval i zahraničními zkušenostmi, které ukazovaly, že „tělesná práce vychovává $k$ zcela jinému nazírání na dělníka a sbližuje všechny muže jedním duchem družnosti “ ${ }^{24}$ Realizace tohoto návrhu, jehož konkrétní podoba nebyla zcela připravena, by znamenala faktické zavedení pracovní povinnosti. Instituce, jejímž původním cílem bylo přispět ke snížení nezaměstnanosti, by tak získala nový charakter. Argumentace zahraničím odkazuje především $\mathrm{k}$ německému vzoru. Pracovní povinnost byla $\mathrm{v}$ českých zemích skutečně zavedena $\mathrm{v}$ roce 1939 už po vzniku protektorátu Čechy a Morava z rozhodnutí nacistické okupační moci. Pracovní tábory přesto nelze označovat za typicky totalitní opatření, v době hospodářské krize patřily i v demokratických státech $\mathrm{k}$ běžně užívaným instrumentům. Tento fakt je především důkazem všeobecného odklonu od liberalismu a posilování státní regulace i kolektivistických př́stupů v sociální politice zemí postižených „velkou depresí". Příklon ke státní regulaci trhu práce umožnila i předchozí zkušenost z fungování válečné řízené ekonomiky. V př́ípadě druhé republiky upadající kredit tržní ekonomiky a demokracie znovu a ještě výrazněji ovlivnil Mnichov a jeho důsledky. Stát žádající oběti po svých občanech sám stále víc prohluboval svou závislost na nacistickém Německu a ztrácel tak svou důvěryhodnost. Vládnoucí politická reprezentace druhé republiky se ostatně dostala $\mathrm{k}$ moci jedině $\mathrm{v}$ důsledku předchozí kapitulace pod nátlakem nepřátel $\mathrm{i}$ dřívějších spojenců. ${ }^{25}$ Ani budovatelská rétorika nemohla zakrýt problematickou legitimitu pomnichovské vládnoucí reprezentace, dále oslabovanou stále viditelnějším nátlakem nacistického Německa. Zůstává předmětem diskuzí, nakolik kroky vlád druhé republiky určoval tento tlak a nakolik vycházely $\mathrm{z}$ domácích zdrojů. Zde se otevírá prostor pro další výzkum, jenž by analyzoval míru kontinutity pomnichovské sociální politiky s předchozím obdobím.

\section{Literatura}

[1] DEYL, Z., 1985. Sociální dějiny Československa 1918-1938. Praha: Academia. Bez ISBN.

[2] DOBEŠ, J., 2009. Nečekané paralely aneb proudy skryté pod povrchem mocenských změn. Soudobé dějiny, 16(4), 653-664. ISSN 1210-7050.

[3] FIELD, J., 2009. Able Bodies. Work camps and the training of the unemployed in Britain before 1939 [online]. [vid. 20. března. 2013]. Dostupné $\mathrm{z}<\mathrm{http} / / / \mathrm{www} . i o e . s t i r . a c . u k$ /staff/documents/ScutreaJFprecamps2009.pdf>

[4] GEBHART, J. a J. KUKLÍK, 2004. Druhá republika 1938-1939. Svár demokracie a totality. Praha: Paseka. ISBN 80-7185-626-6.

[5] HAVELKA, M., 2009. Srovnání nesrovnatelného aneb Existovala v českých dějinách epocha totalitarismu? Soudobé dějiny, 16(4), 607-625. ISSN 1210-7050.

[6] JAROŠ, T., 2012 Strana národní jednoty ve druhé republice (1938 - 1939). E-polis.cz [online]. [vid. 30. března 2013]. Dostupné $\mathrm{z}<\mathrm{http}: / /$ www.e-polis.cz/nezarazeneclanky/687-strana-narodni-jednoty-ve-druhe-republice1938-1939.html>. ISSN 18011438.

24 Po dobrých zkušenost přebudováni pracovnich táborů. Polední Lidové listy 4. 2. 1939, č. 29, s. 3.

25 T. Jaroš připomíná, že vládnoucí politická strana nebyla „autentickou reprezentantkou národní jednoty, ale spíše produktem beznaděje a rezignace české politiky“. Jednotící idea deklarovaně celonárodního hnutí „byla budována ex post" (Jaroš, 2012). 
[7] KRÁL, V., 1959. Otázky hospodářského a sociálního vývoje v českých zemích 19381945. III. Praha: Československá akademie věd. Bez ISBN.

[8] KUKLÍK, J., 1993. Sociální demokraté ve Druhé republice. Praha: Karolinum. ISBN X06350.

[9] MATES, P., 1989. Projevy fašizace v českých zemích za tzv. druhé republiky. Právněhistorické studie, 29, 157-184. ISBN 80-246-0579-1.

[10] POKORNÝ, J., 1999. Odbory po Mnichovu. Vznik Národní odborové ústředny zaměstnanecké. Pohledy. Revue pro politiku, ekonomii, sociologii a historii, 7(3), 15-17. ISSN 1213-3973.

[11] PREČAN, V. 1994. Problémy českého stranického systému mezi Mnichovem 1938 a květnem 1945. In: V kradeném čase. Výběr ze studií, článků a úvah z let 1973-1993. Praha: Ústav pro soudobé dějiny AV ČR. ISBN 80-825270-31-5.

[12] PRŮCHA, V. a kol., 2004. Hospodářrské a sociální dějiny Československa 1918-1992. I. díl. Obdobi 1918-1945. Brno: Doplněk. ISBN 80-7239-147-X.

[13] RÁKOSNÍK, J. a J. NOHA, 2012. Kapitalismus na kolenou. Dopad velké hospodářské krize na evropskou společnost 1929-1934. Praha: Auditorium. ISBN 978-80-87284-29-2.

[14] RÁKOSNÍK, J., 2008. Odvrácená tvár̆ meziválečné prosperity. Nezaměstnanost v Československu v letech 1918-1938. Praha: Karolinum. ISBN 978-80-246-1429-8.

[15] RATAJ, J., 1997. O autoritativní národní stát. Ideologické proměny české politiky $v$ druhé republice 1938-1939. Praha: Karolinum. ISBN 80-7184-516-7.

[16] SALMOND, J., 1967. The Civilian Conservations Corps. A New Deal Case Study [online]. [vid. 12. června 2013]. Dostupné $\mathrm{z} \quad<$ http://www.nps.gov/ history/history/online_books/ccc/salmond/>

[17] SEDLÁKOVÁ, M., 2004. Pracovně výchovné tábory. In: Nucené pracovní nasazení českého obyvatelstva v letech 2. světové války. Museli pracovat pro Řiší. Sborník ze semináře konaného ve Státním ústředním archivu v Praze dne 2. dubna 2004. Praha: Státní ústřední archiv, s. 138-147. 